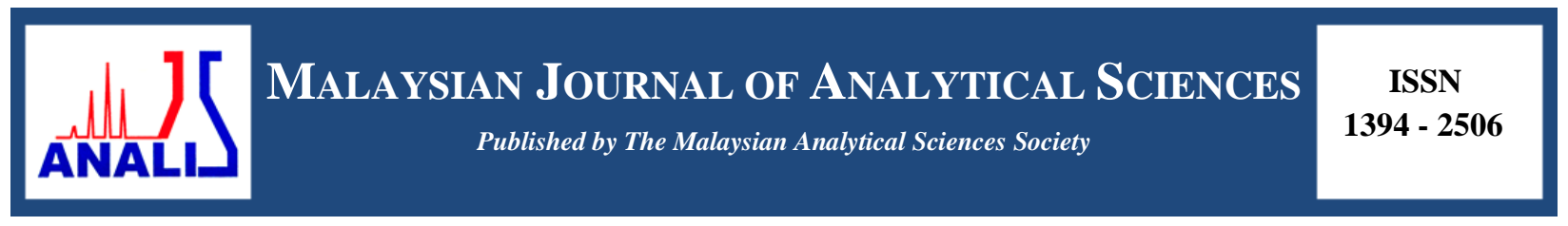

\title{
DIKETOPIPERAZINE PRODUCED BY PSYCHROPHILIC YEAST Glaciozyma antarctica PI12
}

\section{(Diketopiperazin Dihasilkan oleh Yis Psikropilik Glaciozyma antarctica PI12)}

\author{
Andi Rifki Rosandy ${ }^{1}$, Muntaz Abu Bakar ${ }^{1}$, Nurul Nadiah Abdul Rahman ${ }^{1}$, Abdul Munir Abdul Murad², \\ Azira Muhamad ${ }^{3}$, Rozida Mohd. Khalid ${ }^{1 *}$ \\ ${ }^{\text {IS }}$ chool of Chemical Science and Food Technology, Faculty of Science and Technology \\ ${ }^{2}$ School of Biosciences and Biotechnology, Faculty of Science and Technology \\ Universiti Kebangsaan Malaysia, 43600 UKM Bangi, Selangor, Malaysia \\ ${ }^{3}$ Malaysia Genome Institute (MGI), \\ National Institute of Biotechnology Malaysia, Jalan Bangi, 43000 Kajang, Selangor, Malaysia \\ *Corresponding author: rozidakhalid@ukm.edu.my
}

Received: 7 June 2017; Accepted: 1 November 2017

\begin{abstract}
Four diketopiperazine derivatives; cyclo(-Pro-Val) (1), (-)-cyclo(-Pro-Tyr) (2), (-)-cyclo(-Pro-Phe) (3) and (+)-cyclo(-Pro-Leu) (4) were isolated from the ethyl acetate extract of Glaciozyma antarctica PI12, a cold-adapted yeast that belongs to family Kriegeriales. The compounds were isolated by radial chromatography and thin layer chromatography techniques and the chemical structures were elucidated by infrared (IR), ultraviolet (UV), nuclear magnetic resonance (NMR) spectroscopy and mass spectrometry.
\end{abstract}

Keywords: Glaciozyma antarctica PI12, diketopiperazine, Kriegeriales

\section{Abstrak}

Empat terbitan diketopiperazin; siklo(-Pro-Val) (1), (-)-siklo(-Pro-Tir) (2), (-)-siklo(-Pro-Phe) (3) and (+)-siklo(-Pro-Leu) (4) yang dipencilkan daripada ektrak etil asetat Glaciozyma antarctica PI12, merupakan yis adaptasi sejuk yang terdiri dari famili Kriegeriales. Sebatian - sebatian terpencil telah diasingkan menggunakan teknik kromatografi pepejal dan kromatografi lapisan nipis dan struktur kimia dijelaskan oleh spektroskopi infra merah (IM), ultra lembayung (UL), resonans magnetik nuklear (RMN) dan spektrometri jisim.

Kata kunci: Glaciozyma antarctica PI12, diketopiperazin, Kriegeriales

\section{Introduction}

Antarctica is a continent with extreme low temperature and nutrients, with high UV radiation, low water availabilities and frequent freeze-thaw cycle [1]. Therefore, the biology of Antarctica more than other continents, is dominated by microorganisms [2], with a high level of adaptation and able to withstand extreme condition [3]. However, temperature is one of major factors affecting the survival of microorganisms in Antarctica [4]. Cold adapted fungi that grow optimally at temperatures less than $15{ }^{\circ} \mathrm{C}$ and cannot grow above $20{ }^{\circ} \mathrm{C}$ are called "psychrophilic fungi or cold-adapted fungi" [5]. Since the 1960s, bioactive secondary metabolites have been isolated and structurally characterised from psychrophiles [6] such as bioactive non-ribosomal peptides (NRPs), 
compounds derived from the NRP-synthetase that were developed into antibiotics i.e. bacitracin, polymyxin B and E [7].

Glaciozyma antarctica PI12 belongs to the family Kriegeriales [8] and was isolated from a marine environment in Antarctica [9]. Recently, this psychrophilic yeast was reclassified from Leucosporidium antarcticum to Glaciozyma antarctica PI12 [10] and has also been isolated from various locations in Antarctica [11, 12]. Glaciozyma antarctica PI12 was widely investigated in recent yearsin most antifreeze protein production and cold-active enzyme, including an extracellular serine proteinase [13]. The main objective of this paper is to describe the isolation and structure characterisation from psychrophilic yeast G. antarctica PI12.

\section{Biological materials}

\section{Materials and Methods}

The G. antarctica PI12 sample used was a gift from Prof. Dr. Nazalan Najimudin from Universiti Sains Malaysia in Penang, Malaysia. It was identified based on the biochemical characteristics and the sequence of the internal transcribed spacer (ITS) as well as the LSU rRNA (Accession numbers JX89896955 and JX896956) by the National Collection of Yeast Cultures, Norwich, UK. The strain was cultured on Tryptic Soy Agar for 10 days at 4 ${ }^{\circ} \mathrm{C}$ until a single colony was obtained [14]. The culturing of $G$. antarctica PI12 was conducted in collaboration with the Malaysia Genome Institute.

\section{Cultivation of yeast}

$10 \mu \mathrm{L}$ of the G. antarctica PI12's glycerol stock was sub-cultured on the Yeast Extract-Peptone-Dextrose (YPD) agar with $50 \mu \mathrm{g} / \mathrm{mL}$ of ampicillin and $50 \mu \mathrm{g} / \mathrm{mL}$ of kanamycin at $12{ }^{\circ} \mathrm{C}$ until a single colony was obtained. Next, a starter culture of $G$. antarctica PI12 was prepared by inoculating a single colony of $G$. antarctica PI12 from the agar plate into $10 \mathrm{~mL}$ of YPD medium ( $50 \mathrm{~mL}$ falcon tube) with $50 \mu \mathrm{g} / \mathrm{mL}$ of ampicillin and $50 \mu \mathrm{g} / \mathrm{mL}$ of kanamycin. It was then cultured at $12{ }^{\circ} \mathrm{C}$ at $180 \mathrm{rpm}$ until mid-log phase (OD600: 1.0 to 1.8) (5 days). Thirdly, a fixed amount $\left(10^{6}\right.$ yeast cells $\left./ \mathrm{mL}\right)$ of starter culture was inoculated into $50 \mathrm{~mL}$ of YPD medium (three $250 \mathrm{~mL}$ of conical flask were used) with two antibiotics, and then cultured at $12{ }^{\circ} \mathrm{C}$ at $180 \mathrm{rpm}$ until stationary phase at day 14 [15].

\section{Extraction and isolation}

The production culture was centrifuged $\left(10,000 \mathrm{rpm}, 4{ }^{\circ} \mathrm{C}, 5 \mathrm{~min}\right)$. The supernatant was filtered under vacuum to remove any cells that were not pelleted out and its $\mathrm{pH}$ was adjusted to 4.0. The supernatant was extracted thrice with ethyl acetate, and concentrated using a rotary evaporator. The ethyl acetate (EtOAc) extract (200.7 mg) of $G$. antarctica PI12 was subjected to radial chromatography (RC) with $1 \mathrm{~mm}$ thickness silica gel on a round glass plate and eluted with the mixtures of dichloromethane (DCM) and methanol $(\mathrm{MeOH})$ with increasing polarity (started with $\mathrm{DCM} / \mathrm{MeOH}, 9.6: 0.4)$. The eluates showing the same profile on thin layer chromatography (TLC) were combined to give three fractions (I-III). Purification of Fraction I (1-4) $(29.7 \mathrm{mg})$ was carried out using RC with a silica gel plate of $0.5 \mathrm{~mm}$ thickness eluted with DCM and $\mathrm{MeOH}(9.2: 0.8)$ in 5\% polarity increment to yield Compound $1(1 \mathrm{mg})$. Purification of Fraction III (5-7) $(48.8 \mathrm{mg})$ was conducted by utilising another RC with silica gel plate of $0.5 \mathrm{~mm}$ thickness. Elution with DCM and $\mathrm{MeOH}$ (8.4: 1.6) produced Compound 2 (1 mg), Compound 3 (1.5 mg), and Compound 4 (2 mg).

\section{Characterization study}

\section{Results and Discussion}

Cyclo(-Pro-Val) (1) is a white amorphous solid. ESI-MS $[M+\mathrm{H}]^{+}$at $m / z: 197$. IR $\bar{v}_{\max }\left(\right.$ ATR) $\mathrm{cm}^{-1}: 3191,2956$, 1640, 1453, 1110, 922. ${ }^{1} \mathrm{H}$ NMR (MeOD, $\left.700 \mathrm{MHz}\right) \delta_{\mathrm{H}}(\mathrm{ppm})$ and ${ }^{13} \mathrm{C} \mathrm{NMR}(\mathrm{MeOD}, 175 \mathrm{MHz}) \delta_{\mathrm{C}}(\mathrm{ppm})$ data are tabulated in Table 1.

(-)-Cyclo(-Pro-Tyr) (2) is a white amorphous solid. $[\alpha]_{\mathrm{D}}^{20}-43.1$ (c 0.14, ethanol). ESI-MS $[\mathrm{M}+\mathrm{H}]^{+}$ion at $m / z: 261$. IR $\bar{v}_{\max }$ (ATR) $\mathrm{cm}^{-1}: 3248,2927,2853,1747,1658,1449,1252,1174,1114,1017,858 .{ }^{1} \mathrm{H}$ NMR (MeOD, 700 $\mathrm{MHz}) \delta_{\mathrm{H}}(\mathrm{ppm})$ and ${ }^{13} \mathrm{C}$ NMR $(\mathrm{MeOD}, 175 \mathrm{MHz}) \delta_{\mathrm{C}}(\mathrm{ppm})$ data are tabulated in Table 1. 
(-)-Cyclo(-Pro-Phe) $(3)$ is a white amorphous solid. $[\alpha]_{\mathrm{D}}^{20}-72\left(\mathrm{c} 0.7\right.$, methanol). ESI-MS $[\mathrm{M}+\mathrm{H}]^{+}$ion at $m / z: 169$. IR $\bar{v}_{\max }\left(\right.$ ATR) $\mathrm{cm}^{-1}: 3357,2956,2108,1647,1449,1318$ and 1087. ${ }^{1} \mathrm{H}$ NMR (MeOD, $\left.700 \mathrm{MHz}\right) \delta_{\mathrm{H}}(\mathrm{ppm})$ and ${ }^{13} \mathrm{C}$ NMR (MeOD, $175 \mathrm{MHz}) \delta_{\mathrm{C}}(\mathrm{ppm})$ data are tabulated in Table 1.

(+)-Cyclo(-Pro-Leu) (4) is a white powder. $[\alpha]_{\mathrm{D}}^{20}+28.1\left(c 0.032\right.$, ethanol). ESI-MS $[\mathrm{M}+\mathrm{H}]^{+}$ion at $m / z: 211$. IR $\bar{v}_{\max }($ ATR $) \mathrm{cm}^{-1}: \quad 3222,2958,2930,2872,1686,1676,1426,1302,1275,1235,1157,1102,1032,996-919 .{ }^{1} \mathrm{H}$ NMR (MeOD, $700 \mathrm{MHz}) \delta_{\mathrm{H}}(\mathrm{ppm})$ and ${ }^{13} \mathrm{C}$ NMR $(\mathrm{MeOD}, 175 \mathrm{MHz}) \delta_{\mathrm{C}}(\mathrm{ppm})$ data are tabulated in Table 1.

Table 1. ${ }^{1} \mathrm{H}$ and ${ }^{13} \mathrm{C}$ NMR data (700 and $175 \mathrm{MHz}, \mathrm{MeOD}$ ) for compounds 1-4

\begin{tabular}{|c|c|c|c|c|c|c|c|c|}
\hline \multirow{2}{*}{ Position } & \multicolumn{4}{|c|}{ APT (ppm) } & \multicolumn{4}{|c|}{${ }^{1} \mathbf{H}($ mult., $\left.\Sigma \mathbf{H})\right)$} \\
\hline & 1 & 2 & 3 & 4 & 1 & 2 & 3 & 4 \\
\hline $1-\mathrm{N}$ & - & - & - & - & - & - & & - \\
\hline 2 & 165.8 & 165.7 & 165.5 & 167.1 & - & - & - & - \\
\hline 3 & 59.9 & 56.6 & & 53.1 & $3.92(d, 1 \mathrm{H})$ & $4.37(m, 1 \mathrm{H})$ & $4.25(t, 1 \mathrm{H})$ & $4.00(t, 1 \mathrm{H})$ \\
\hline $4-\mathrm{NH}$ & - & - & - & - & $\begin{array}{l}7.93(b r-s, \\
1 \mathrm{H})\end{array}$ & $7.65(s, 1 \mathrm{H})$ & $7.62(s, 1 \mathrm{H})$ & $\begin{array}{l}7.99(b r-s, \\
1 \mathrm{H})\end{array}$ \\
\hline 5 & 170.9 & 169.6 & 169.3 & 171.1 & - & - & - & - \\
\hline 6 & 58.7 & 58.7 & 58.6 & 58.9 & $4.11(t, 1 \mathrm{H})$ & $4.05(m, 1 \mathrm{H})$ & $4.14(t, 1 \mathrm{H})$ & $4.18(t, 1 \mathrm{H})$ \\
\hline \multirow[t]{2}{*}{7} & 28.3 & 28.0 & 28.0 & 27.9 & $1.82(m, 1 \mathrm{H})$ & $2.33(q, 1 \mathrm{H})$ & $2.29(m, 1 \mathrm{H})$ & $2.12(q, 1 \mathrm{H})$ \\
\hline & & & & & $2.14(m, 1 \mathrm{H})$ & $1.99(q, 1 \mathrm{H})$ & $1.92(q, 1 \mathrm{H})$ & $1.89(q, 1 \mathrm{H})$ \\
\hline \multirow[t]{2}{*}{8} & 22.4 & 21.4 & 21.3 & 22.9 & $1.80(m, 1 \mathrm{H})$ & $2.01(m, 1 \mathrm{H})$ & $2.01(m, 1 \mathrm{H})$ & $1.91(m, 1 \mathrm{H})$ \\
\hline & & & & & $1.86(m, 1 \mathrm{H})$ & $1.93(m, 1 \mathrm{H})$ & $1.93(m, 1 \mathrm{H})$ & $1.80(m, 1 \mathrm{H})$ \\
\hline \multirow[t]{2}{*}{9} & 45.1 & 44.6 & 44.5 & 45.3 & $3.33(t, 1 \mathrm{H})$ & $3.63(m, 1 \mathrm{H})$ & $3.68(\mathrm{~m}, 1 \mathrm{H})$ & $3.36(t, 1 \mathrm{H})$ \\
\hline & & & & & $3.38(t, 1 \mathrm{H})$ & $3.57(m, 1 \mathrm{H})$ & $3.58(\mathrm{~m}, 1 \mathrm{H})$ & $3.37(t, 1 \mathrm{H})$ \\
\hline \multirow[t]{2}{*}{10} & 28.2 & 36.3 & 36.3 & 38.1 & $2.32(m, 1 \mathrm{H})$ & $3.46(d d, 1 \mathrm{H})$ & $3.47(\mathrm{dd}, 1 \mathrm{H})$ & $1.75(t, 1 \mathrm{H})$ \\
\hline & & & & & & $2.79(d d, 1 \mathrm{H})$ & $2.79(\mathrm{dd}, 1 \mathrm{H})$ & $1.36(t, 1 \mathrm{H})$ \\
\hline 11 & 18.7 & - & - & 24.5 & $0.99(d, 3 \mathrm{H})$ & - & - & $1.85(m, 1 \mathrm{H})$ \\
\hline 12 & 16.7 & - & - & 23.2 & $0.83(d, 3 \mathrm{H})$ & - & - & $0.86(d, 3 \mathrm{H})$ \\
\hline 13 & - & - & - & 22.3 & - & - & - & $0.85(d, 3 \mathrm{H})$ \\
\hline 1 & - & 126.3 & 126.2 & - & - & - & - & - \\
\hline $2 / 6$ & - & 130.7 & 130.7 & - & - & $7.05(d d, 2 \mathrm{H})$ & $7.02(\mathrm{dd}, 2 \mathrm{H})$ & - \\
\hline $3 / 5$ & - & 115.0 & 130.3 & - & - & $6.79(d d, 2 \mathrm{H})$ & $6.73(\mathrm{dd}, 2 \mathrm{H})$ & - \\
\hline 4 & - & 156.1 & 128.2 & - & - & $\begin{array}{l}5.35(b r-s, 1 \mathrm{H}), \\
-\mathrm{OH}\end{array}$ & $7.24(\mathrm{~d}, 1 \mathrm{H})$ & - \\
\hline
\end{tabular}

Compound 1 was isolated as white amorphous solid. Its molecular formula was determined as $\mathrm{C}_{10} \mathrm{H}_{16} \mathrm{~N}_{2} \mathrm{O}_{2}$, obtained by ESI-MS $[\mathrm{M}+\mathrm{H}]^{+} \mathrm{m} / \mathrm{z} 197$. The IR spectrum showed the presence of carbonyl groups from amide $\left(1640 \mathrm{~cm}^{-1}\right)$, and also saturated methylene groups at the range of $2956-2889 \mathrm{~cm}^{-1}$. The ${ }^{13} \mathrm{C}$-APT NMR spectrum showed the location of ten signals representing two quaternary, three methines, three methylenes and two methyls carbons. The double bond equivalent (DBE) value of four indicated that this compound contained two double bonds and two cyclic aliphatic. The most deshielded carbons at $\delta_{\mathrm{C}} 170.9$ and $165.8 \mathrm{ppm}$ were indicated as an asymmetrical carbonyl group. Three saturated non-equivalent methylenes signals at $\delta_{\mathrm{C}} 28.3$ (C-7), 22.4 (C-8) and 45.1 (C-9) were attributed to a pyrrolidine ring. A methine carbon at $\delta_{\mathrm{C}} 58.7 \mathrm{ppm}(\mathrm{C}-6)$ was the specific of methine signal of diketopiperazine alkaloid and another one methine at $\delta_{C} 59.9 \mathrm{ppm}(\mathrm{C}-3)$ indicated the presence of a methine existed 
between carbonyl and secondary amide while the two non-equivalent gem-dimethyls at $\delta_{\mathrm{C}} 18.7 \mathrm{ppm}(\mathrm{C}-11)$ and $\delta_{\mathrm{C}}$ $18.7 \mathrm{ppm}(\mathrm{C}-12)$ bound a saturated methine at $\delta_{\mathrm{C}} 28.2 \mathrm{ppm}(\mathrm{C}-10)$.

Meanwhile, 12 proton signals representing 16 protons appeared in the ${ }^{1} \mathrm{H}-\mathrm{NMR}$ spectrum as shown in Table 1 . Six of the signals came from the three non-equivalent methylenes proton at H-7, H-8 and H-9, forming a basic pyrrolidine ring. An aminated methine proton, $\mathrm{H}-6\left(\delta_{\mathrm{H}} 4.11 \mathrm{ppm}\right)$ resonated as a triplet, indicating that C-6 was adjacent to a methylene group (C-7). Another methine proton at $\mathrm{H}-10\left(\delta_{\mathrm{H}} 2.32 \mathrm{ppm}\right)$ was resonated as a multiplet, because it was bound to two non-equivalent gem-dimethyls at $\mathrm{C}-11$ and $\mathrm{C}-12$. Comparison of the ${ }^{1} \mathrm{H}$ and ${ }^{13} \mathrm{C}$-APT NMR spectra of the compound suggested that it was Cyclo(-Pro-Val) (Fig. 1) [16]. Thus, the structure of Cyclo(Pro-Val) (1) was previously isolated from Aspergillus fumigatus [17], Pseudomonas aeruginosa [18], and Stenotrophomonas sp. [19].

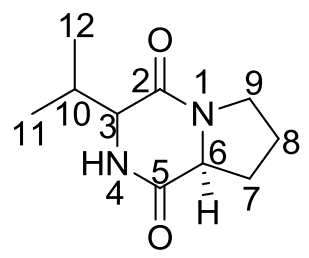

Figure 1. Chemical structure of compound 1

Compounds 2 and 3 (Figure 2) were found in Fraction III as a UV absorbing spot, which stained to violet with anisaldehyde/sulphuric acid. The ${ }^{1} \mathrm{H}$ NMR spectrum of Compound 2 showed two ortho-coupled signals at $\delta_{\mathrm{H}} 7.05$ $\left(\mathrm{H}-2^{\prime}, 6^{\prime}\right)$ and $6.79\left(\mathrm{H}^{-} 3^{\prime}, 5^{\prime}\right)$, which pointed to an AA'-BB' system of a 1,4-disubstituted aromatic ring, as well as two signals at $\delta 4.37$ and 4.05 for two methines attached to electron withdrawing substituents. The spectrum proton of Compound 2 showed also two doublet of doublets for an ABX system of a methylene group at $\delta_{\mathrm{H}} 3.46$ and 2.79 $\left(\mathrm{CH}_{2}-10\right)$, as well as three methylene multiplets $\left(\mathrm{CH}_{2}-7\right)\left(\delta_{\mathrm{H}} 2.33,1.99\right)$ attached to a heteroatom and $\mathrm{CH}_{2}-8,9\left(\delta_{\mathrm{H}}\right.$ $2.01,1.93,3.63,3.57)$. The ESI mass spectra determined the molecular weight of Compound 2 as 261 Dalton by (+)-ESI mode. The structure was further confirmed as (-)-cyclo(-Pro-Tyr) (2) by comparison with an authentic sample and spectra from our collection [20]. (-)-cyclo(-Pro-Tyr) (2) was previously isolated from Pseudomonas fluorescens GcM5-1A [21], Streptomyces sp. H7372 and ML 1532 [22, 23], Pseudomonas aeruginosa [18] and Lysobacter capsici AZ78 [24]. The difference between Compound 2 and Compound 3 lay on C-4, where Compound 2 had a hydroxy at C-4` (Figure 2).

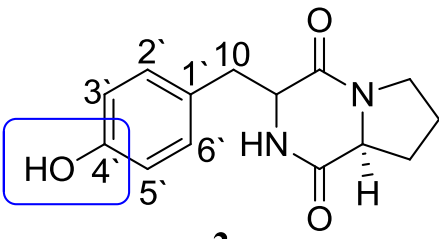

2

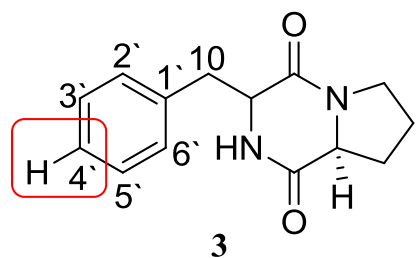

3

Figure 2. Structure of compounds $\mathbf{2}$ and $\mathbf{3}$

From the spectroscopy data and comparison with the literature, compound $\mathbf{3}$ was confirmed as (-)-cyclo(-Pro-Phe) (3) [17] previously isolated from microbial sources, including Streptomyces rochei 87051-3 [16], Streptomyces sudanensis. A4.4 [25], Tyridiomyces formicarum [26], and Alternaria alternata [27].

(+)-Cyclo(-Pro-Leu) (4), $[\alpha]_{\mathrm{D}}^{20}+28.1(c 0.032$, ethanol), was isolated as a white amorphous material with molecular formula $\mathrm{C}_{11} \mathrm{H}_{18} \mathrm{~N}_{2} \mathrm{O}_{2}$, obtained by ESI-MS $[\mathrm{M}+\mathrm{H}]^{+} \mathrm{m} / \mathrm{z} 211$. The IR spectrum showed bands attributed to the aliphatic carbons $\left(2958,2930,2872 \mathrm{~cm}^{-1}\right)$ and amide $\left(1686,1676 \mathrm{~cm}^{-1}\right)$ functional groups. The ${ }^{1} \mathrm{H}$ NMR spectrum 
of compound 4 indicated the presence of three methines at H-3, H-6 and H-11; four methylenes at H-7, H-8, H-9 and $\mathrm{H}-10$; and two non-equivalent dimethyls at $\mathrm{H}-12$ and $\mathrm{H}-13$ (Table 1). ${ }^{13} \mathrm{C}$ NMR spectrum exhibited the presence of 11 carbon signals corresponding to two methyls, four methylenes, three methines and two quaternary carbons. The observation of the quaternary carbons at $\delta_{\mathrm{C}} 167.1(\mathrm{C}-2)$ and $171.1(\mathrm{C}-5)$ suggested that these carbon signals were due to the carbonyl carbon of the amide groups. The DBE value of four indicated that this compound was containing two double bonds and two cyclic aliphatic. (+)-cyclo(Pro-Leu) (4) previously isolated from the Gramnegative Proteobacteria of Burkholderia cenocepacia and Serratia marcescens [28], Alternaria alternata [29], the bacteria Pseudoalteromonas sp. [30] and Vibrio alginolyticus [31].

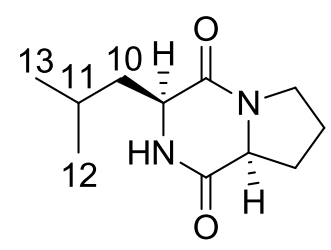

Figure 3. Structure of compounds 4

\section{Conclusion}

Four diketopiperazine derivatives, i.e. cyclo(-Pro-Val) (Compound1), (-)-cyclo(-Pro-Tyr) (Compound 2), (-)-cyclo(Pro-Phe) (Compound3) and (+)-cyclo(-Pro-Leu) (Compound4) were isolated and reported for the first time from psychrophilic yeast $G$. antarctica PI12. All the compounds reported in the present study were not subjected to further bioactivity studies due to insufficient amounts.

\section{Acknowledgement}

We would like to thank the School of Chemical Sciences and Food Technology, Faculty of Science and Technology, Universiti Kebangsaan Malaysia (UKM); Malaysia Genome Institute (MGI) for providing research facilities. We would like also to express our gratitude to the Indonesia Endowment Fund for Education (LPDP) and the Malaysian Ministry of Science and Technology and Universiti Kebangsaan Malaysia for financial support through the following research grants: 02-05-20-SF0007/4 and FRGS-1-2014-SG01-UKM-02-6.

\section{References}

1. Ruisi, S., Barreca, D., Selbmann, L., Zucconi, L. and Onofri, S. (2007). Fungi in Antarctica. Reviews in Environmental Science and Biotechnology, 6: 127 - 141.

2. Nienow, J. A. and Friedmann, E. I. (1993). Terrestrial litophytic (rock) communities. In: Friedmann, E. I. (ed). Antarctica microbiology. Wiley-Liss, New York, pp. $343-412$.

3. Friedmann, E. I. (1993). Antarctic microbiology. Wiley-Liss, New York, pp. 634.

4. Morgan-Kiss, R. M., Priscu, J. C., Pocock, T., Gudynaite-Savitch, L. and Humer, N. P. (2006). Adaptation and acclimation of photosynthetic microorganisms to permanently cold environments. Microbiology and Molecular Biology Reviews, 70: 222 - 252.

5. Morgan, R. Y. (1975). Psychrophilic bacteria. Bacteriological Reviews, 39: 144 - 167.

6. Giddings, L. A. and Newman, D. J. (2015). Bioactive compounds from terrestrial extremophiles. Springer, New York, pp. 1.

7. Sewald, N. and Jakubke, H. D. (2002). Peptides: Chemistry and biology. NJ: Wiley, Berlin, pp. 119 -124.

8. Di Menna, M. E. (1960). Yeast from Antarctica. Journal of General Microbiology, 7: 295 - 300.

9. Fell, J. W., Statzell, A., Hunter, I. L. and Phaff, H. J. (1969). Leucosporidium gen. n., the heterobasidiomycetous stage of several yeasts of the genus Candida. Antonie van Leeuwenhoek, 35: 433 - 462.

10. Turchetti, B., Thomas-Hall, S. R., Connell, L. B., Branda. E., Buzzini, P., Theelen, B., Müller, W. H. and Boekhout, T. (2011). Psychrophilic yeasts from Antarctica and European glaciers: description of Glaciozyma gen. nov., Glaciozyma martinii sp. nov. and Glaciozyma watsonii sp. nov. Extremophiles, 15: 573 - 586. 
11. Donachie, S. P. (1995). Ecophysiological description of marine bacteria from Admiralty Bay (Antarctica), and the digestive tracts of selected Euphausiidae. Ph.D. Thesis, Department of Antarctic Biology, Polish Academy of Sciences, Warsaw.

12. Connell, L. B., Redman, R., Craig, S., Scorzetti, G., Iszard, M. and Rodriguez, R. (2008). Diversity of soil yeasts isolated from South Victoria Land, Antarctica. Microbial Ecology, 56: 448 - 459.

13. Pazgier, M., Turkiewicz, M., Kalinowska, H. and Bielecki, S. 2003. The unique cold-adapted extracellular subtilase from psychrophilic yeast Leucosporidium antarcticum. Journal of Molecular Catalysis B: Enzymatic, 21: $39-42$.

14. Hashim, N. H. F., Sulaiman, S., Bakar, F. D. A., Illias, R. M., Kawahara, H., Najimudin, N., Mahadi, N. M. and Murad, A. M. A. (2014). Molecular cloning, expression and characterisation of Afp4, an antifreeze protein from Glaciozyma antarctica. Polar Biology, 37: 1495 - 1505.

15. Hashim, N. H. F., Bharudin, I., Nguong, D. L. S., Higa, S., Bakar, F. D. A., Nathan, S., Rabu, A., Kawahara, H., Illias. R. M., Najimudin, N., Mahadi, N. M. and Murad, A. M. A. (2013). Characterization of Afp1, an antifreeze protein from the psychrophilic yeast Glaciozyma antarctica PI12. Extremophiles, 17: 63 - 73.

16. Lee, H. B., Choi, Y. C. and Kim, S. U. (1994). Isolation and identification of Maculosins from Streptomyces rochei 87051-3. Agricultural Chemistry and Biotechnology, 37(5): $339-342$.

17. Furtado, N. A. J. C., Pupo, M. T., Carvalho, I., Campo, V. L., Duarte, M. C. T., and Bastos, J. K. (2005). Diketopiperazines produced by an Aspergillus fumigatus Brazilian strain. Journal of the Brazilian Chemical Society, 16(6B): $1448-1453$.

18. Vasquez-Rivera, D., González, O., Guzmán-Rodríguez, J., Diaz-Pérez, A. L., Ochoa-Zarzosa, A., Lopez-Bucio, J., Meza-Carmen, V. and Campos-García, G. (2015). Cytotoxicity of cyclodipeptides from Pseudomonas aeruginosa PAO1 leads to apoptosis in human cancer cell lines. BioMed Research International, 2015: 1 - 9.

19. Jermnak, U., Chinaphuti, A., Poapolathep, A., Kawai, R., Nagasawa, H. and Sakuda, S. (2013). Prevention of aflatoxin contamination by a soil bacterium of Stenotrophomonas sp. that produces aflatoxin production inhibitors. Microbiology, 159: 902 - 912.

20. Laatsch, H. (2010). AntiBase a data base for rapid dereplication and structure determination of microbial natural products. Wiley-VCH. Germany, Wein-heim.

21. Guo, Q., Guo, D., Zhao, B., Xu, J. and Li, R. (2007). Two cyclic dipeptides from Pseudomonas fluorescens GcM5-1A carried by the pine wood nematode and their toxicities to Japanese black pine suspension cells and seedlings in vitro. Journal of Nematology, 39(3): 243 - 247.

22. Cheenpracha, S., Borris, R. P., Tran, T. T., Jee, J. M., Seow, H. F., Cheah, H. Y., Ho, C. C. and Chang, L. C. (2011). Three new amides from Streptomyces sp. H7372. Journal of the Brazilian Chemical Society, 22(2): $223-229$.

23. Munekata, M. and Tamura, G. (1981). Selective inhibition of SV40-transformed cell growth by diketopiperazines. Agricultural and Biological Chemistry, 45(11): 2613 - 2618.

24. Puopolo, G., Cimmino, A., Palmieri, M. C., Giovannini, O., Evidente, A. and I. Pertot, I. (2014). Lysobacter capsici AZ78 produces cyclo(L-Pro-L-Tyr), a 2,5-diketopiperazine with toxic activity against sporangia of Phytophthora infestans and Plasmopara viticola. Journal of Applied Microbiology, 117: 1168-1180.

25. Hamza, A. A., Ali, H. A., Clark, B. R., Murphy, C. D. and Elobied, E. A. (2013). Cyclo (L-phenyl, L-prolyl). Diketopiperazines from a newly isolated Streptomyces sudanensis. A4.4. Journal of Biotechnology and Pharmaceutical Research, 4(1): 1 - 7.

26. Wang, Y., Mueller, U. G. and Clardy, J. (1999). Antifungal diketopiperazines from symbiotic fungus of fungusgrowing ant Cyphomyrmex minitus. Journal of Chemical Ecology, 25(4): 935 - 941.

27. Stierle, A. C., Cardellina, J. H. and Strobelt, G. A. (1988). Maculosin, a host-specific phytotoxin for spotted knapweed from Alternaria Alternata. Proceedings of the National Academy of Sciences of the United States of America, 85: 8008 - 8011.

28. Yap, A. C., Kok-Gan Chan, K. G. and Choo, Y. M. (2016). Isolation and identification of metabolites from the Gram-negative proteobacteria of Burkholderia cenocepacia and Serratia marcescens. Sains Malaysiana, 45(7): $1073-1077$.

29. Musetti, R., Polizzotto, R., Vecchione, A., Borselli, S., Zulini, L., D’Ambrosio , M., di Toppi, L. S. and Pertot, I. (2007). Antifungal activity of diketopiperazines extracted from Alternaria alternata against Plasmopara viticola: An ultrastructural study. Micron, 38: 643 - 650 . 
30. Luis, S. M., Ballesteros, J. and Gutiérrez, M. (2011). Antibacterial constituents from the octocoral associated bacterium Pseudoalteromonas sp. Revista Latinoamericana de Química, 39: 1 - 2.

31. Wang, X., Huang, Y., Sheng, Y., Su, P., Qiu, Y., Ke, C. and Feng, D. (2017). Antifouling activity towards mussel by small-molecule compounds from a strain of Vibrio alginolyticus bacterium associated with Sea Anemone Haliplanella sp. Journal of Microbiology and Biotechnology, 27(3): 460-470. 